\title{
Discovery of Novel TRPV1 Ligands through Rational Approach Based on Its Putative Endogenous Ligand, 12(S)-HPETE
}

\author{
Kyung Hoon Min, ${ }^{*}$ Seul Lee, Hwa Soon Kim, ${ }^{\dagger}$ and Young-Ger Suh",

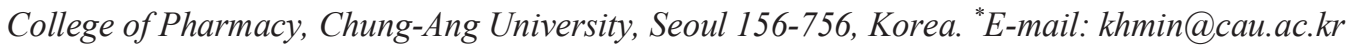 \\ ${ }^{\dagger}$ Seoul Metropolitan Government Research Institute of Public Health and Environment, Seoul 130-864, Korea \\ †College of Pharmacy, Seoul National University, Seoul 151-742, Korea. ${ }^{*} E$-mail: ygsuh@snu.ac.kr \\ Received March 2, 2010, Accepted March 31, 2010
}

\begin{abstract}
We report design and synthesis of the novel TRPV1 ligands through a rational approach. Simplified analogues of 12(S)-HPETE showing TRPV1 agonistic effect are disclosed. Biological evaluation revealed that substitution of functional groups without any change in conformation converted agonist into antagonist. Our work provided key information with regard to TRPV1 agonist/antagonist switching.
\end{abstract}

Key Words: TRPV1, 12(S)-HPETE, Vanilloid receptor, Antagonist

\section{Introduction}

Vanilloid receptor 1 (VR1), recently renamed TRPV1 (transient receptor potential channel, vanilloid subfamily member 1), plays a crucial role as a molecular integrator of multiple pain producing stimuli. ${ }^{1}$ Therefore, it has been suggested that TRPV1 should be a useful therapeutic target for pain and inflammatory hyperalgesia. TRPV1 agonists, like capsaicin and resiniferatoxin (RTX), have been studied clinically as potential treatments for inflammatory and neuropathic pain. ${ }^{2,3}$ However, direct TRPV1 antagonists have the same effect, but without the initial stimulatory and painful responses caused by TRPV1 agonists. ${ }^{4}$ The cloning of TRPV1 initiated a massive effort to discover novel TRPV1 antagonists. ${ }^{5}$ One of the most promising approaches to the development of antagonists involves altering conformation of agonist. Many TRPV1 agonists already have been developed, and the majority of these compounds with a vanilloid group show agonist activity with side effects like initial pungency. Intense structure-activity relationship (SAR) studies on capsaicin have yielded only capsazepine as a small molecule antagonist to date, which has poor metabolic and pharmacokinetic properties. ${ }^{3}$ With regard to the discovery of novel lead molecules without vanilloid moiety, the identification of an endogenous ligand for TRPV1 could provide an opportunity to design new molecules. Thus, we decided to utilize a TRPV1 endogenous ligand instead of random screening or mimicking patented molecules. We have reported previously that $12(S)$ HPETE is a potential ligand for TRPV1, because it has higher activity than endogenous lipids like eicosanoids and conformationally, is similar to capsaicin. ${ }^{6}$ Accordingly, 12(S)-HPETE was utilized to develop antagonists or agonists with novel scaffold and functional groups rather than vanilloids. Herein, we describe the identification of new small molecule antagonists and alternatives to vanilloid based on a putative endogenous ligand, which support the conceptual developmental switch from TRPV1 agonist to antagonist.

\section{Results and Discussion}

Chemistry. Our previous modeling study revealed a high level of conformational similarity between capsaicin and 12(S)HPETE. ${ }^{6}$ Furthermore, the crystal structure of a capsaicin analogue with an agonistic effect was overlapped with that of a complex of capsaicin and 12(S)-HPETE to support this result (Figure 1). Accordingly, we attempted to synthesize small molecules with a carboxylic acid rather than a vanilloid group. If 12(S)-HPETE binds to TRPV1 in the same manner as capsaicin, the distance between the $\mathrm{COOH}$ group and the $\mathrm{OOH}$ group needs to be optimized. The $\mathrm{B}$ region was substituted with heteroatoms to mimic the hydrogen peroxide group of 12(S)-HPETE. (a)

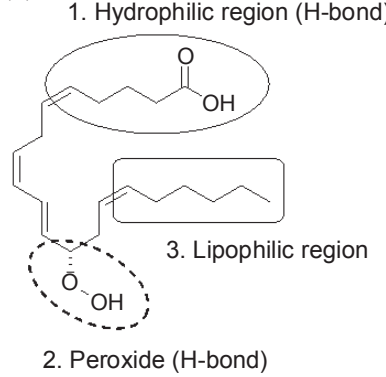

(b)

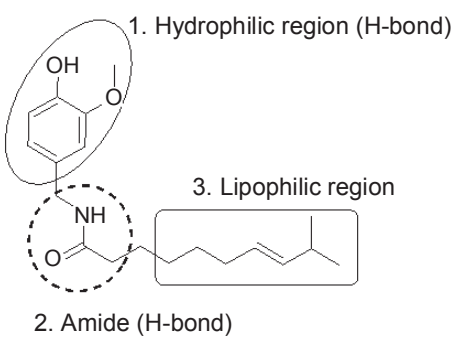

(c)

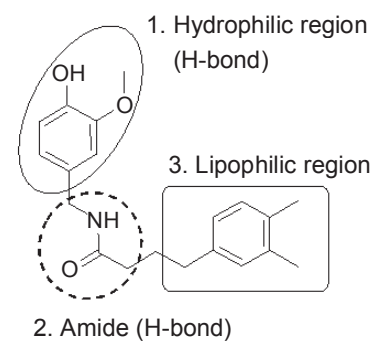

(d)

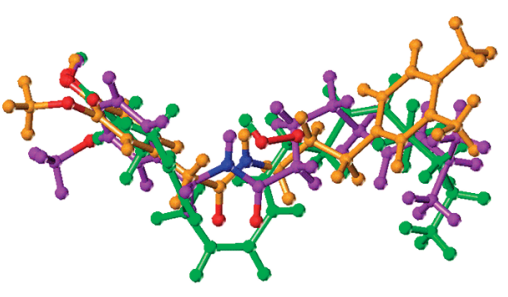

Figure 1. Structural feature of TRPV1 agonist. (a) 12(S)-HPETE (b) capsaicin (c) capsaicinoid. (d) Overlay of $\mathrm{Ca}^{2+}$-influx agonists produced by GASP alignment. 12(S)-HPETE; green, Capsaicin; purple, and Capsaicinoid (crystal structure); orange. 
The distance between the two functional groups in 12(S)-HPETE was controlled to about $7 \AA$ based on the results of our modeling study. The lipophilic $\mathrm{C}$ region was fixed to the phenethyl group before optimization.

Initially, the eicosanoid 12(S)-HPETE was simplified to give compounds $\mathbf{5}$ and $\mathbf{6}$, simplified aliphatic acids with central hetero atoms for hydrogen bonding. Starting material 1 was synthesized in two steps from 1,4-butanediol. ${ }^{7}$ Intermediate 4 was synthesized in an eight-step sequence. Hydroxylamine was introduced as an equivalent of peroxide, and the rigid compound $\mathbf{5}$ and the flexible, saturated compound $\mathbf{6}$ were obtained. We next turned our attention to the synthesis of benzoic acid analogues. Aliphatic carboxylic acid was replaced with benzoic acid while maintaining the distance between pharmacophores. Compound $\mathbf{1 0}$ was designed as a key intermediate to modify the $\mathrm{B}$ region meaningfully. The straightforward reaction sequence (Swern oxidation, ${ }^{8}$ Grignard addition, Pd catalyzed coupling reaction, ${ }^{9}$ hydrogenation and $\mathrm{PDC}$ oxidation) provided ketone $\mathbf{1 0}$ in $50 \%$ overall yield from 7 . Treatment of $\mathbf{1 0}$ with semicarbazides or a hydrazine resulted in the formation of hydrazone, which on methyl ester hydrolysis gave the benzoic acid analogues 11, 12 and 13. Compound 17 with a vanilloid group was also synthesized to explore the effects of the vanilloid and carboxylic acid moieties. Carbamate or thiocarbamate was then introduced to the B region to provide compounds 24-27.

Biological evaluation. Primary cultures of sensory neurons

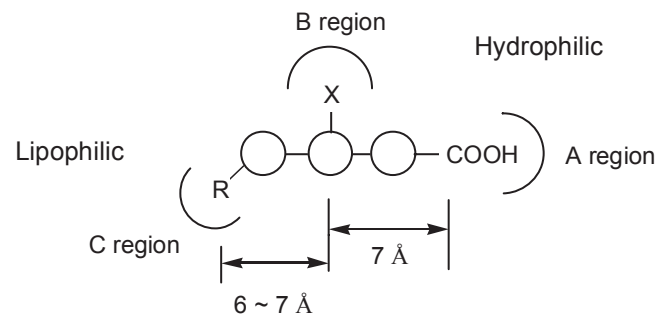

Figure 2. Schematic illustration on design of novel TRPV1 ligands. isolated from dorsal root ganglions of neonatal rats were prepared, and the patch-clamp technique was used to record singlechannel currents as described previously. ${ }^{6}$ As expected, the simplified 12(S)-HPETE's analogues $\mathbf{5}$ and $\mathbf{6}$ showed agonistic activity. On the other hand, semicarbazone $\mathbf{1 1}$ had an antagonistic effect. In contrast, compound $\mathbf{1 7}$ with a vanilloid moiety instead of a carboxylic acid had an agonistic effect. This observation indicates that modification of the vanilloid group can eliminate the agonistic effect. The thiosemicarbazone $\mathbf{1 2}$ had no agonistic activity, whereas the carbamate $\mathbf{2 4}$ and thiocarbamate $\mathbf{2 5}$ exhibited agonistic and antagonistic activities, respectively, revealing that agonist to antagonist switching was achieved by substituting oxygen with sulfur. The $p$-benzoic acid analogue 26 and the $m$-phenylacetic acid analogue 27 were inactive, indicating that an appropriate distance between the functional groups in $\mathrm{A}$ and $\mathrm{B}$ regions is important for maintaining activity. Interestingly, our findings indicate that electronic effect importantly determines the agonistic or antagonistic nature of a compound rather than its conformation. It was found that the substitution of a functional group, in a manner that does not induce a conformational change, can induce agonist/antagonist switching, which suggests that changing functional groups can convert strong agonists to strong antagonists. These findings led us back to the capsaicin scaffold because of its high affinity for TRPV1.

In the present study, we describe the developments of nonvanilloid agonists and antagonists achieved via conformational analysis and functional group screening. Although their activities are weak, we believe that this study provides useful information concerning the development of novel agonists and antagonists.

\section{Materials and Methods}

(E)-4-\{[tert-Butyl(dimethyl)silyl] oxy\}-6-phenyl-2-hexen1-ol (2). To a solution of $\mathbf{1}(2,32 \mathrm{~g}, 10.9 \mathrm{mmol})$ in ether was added dropwise phenethyl magnesium bromide ( $2 \mathrm{M}$ in ether,

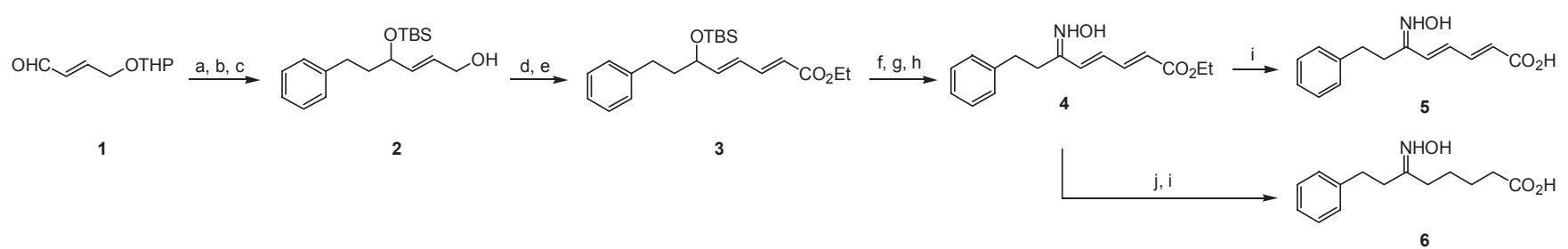

${ }^{a}$ Reaction conditions: (a) $\mathrm{Ph}\left(\mathrm{CH}_{2}\right)_{2} \mathrm{MgBr}$, ether (b) TBSCl, imidazole, DMF (c) $\mathrm{MgBr}_{2}$, ether (d) $\mathrm{MnO}_{2}, \mathrm{CHCl}_{3}$ (e) $\mathrm{Ph}_{3} \mathrm{PCHCO}_{2} \mathrm{Et}, \mathrm{CH}_{2} \mathrm{Cl}_{2}$ (f) TsOH, MeOH (g) PDC, $4 \mathrm{AMS}, \mathrm{CH}_{2} \mathrm{Cl}_{2}$ (h) $\mathrm{NH}_{2} \mathrm{OH}(\mathrm{HCl}), \mathrm{NaOAc}, \mathrm{MeOH}$ (i) $\mathrm{LiOH}, \mathrm{H}_{2} \mathrm{O} / \mathrm{THF}(1: 1)$ (j) $\mathrm{Pd} / \mathrm{C}, \mathrm{H}_{2}$

\section{Scheme $1^{a}$}

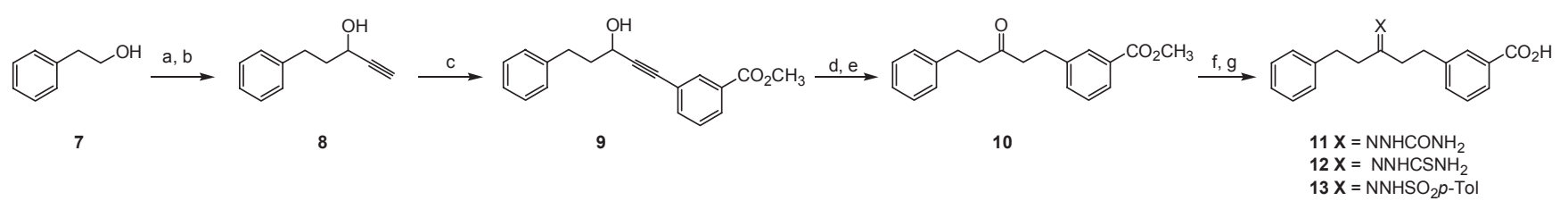

${ }^{a}$ Reaction conditions: (a) $(\mathrm{COCl})_{2}$, DMSO, $\mathrm{Et}_{3} \mathrm{~N}, \mathrm{CH}_{2} \mathrm{Cl}_{2},-78^{\circ} \mathrm{C}$ (b) ethynyl $\mathrm{MgBr}$, ether (c) methyl 3-lodobenzoate, $\mathrm{Cul}_{2}(\mathrm{PPh})_{4} \mathrm{Pd} \mathrm{PPh}, \mathrm{Et}_{3} \mathrm{~N}(\mathrm{~d}) \mathrm{Pd} / \mathrm{C}, \mathrm{H}_{2}, \mathrm{CH}_{3} \mathrm{OH}(\mathrm{e}) \mathrm{PDC}, 4 \mathrm{~A}$ $\mathrm{MS}, \mathrm{CH}_{2} \mathrm{Cl}_{2}$ (f) semicarbazide or thiosemicarbazide or $p$-toluenesulfonylhydrazine, $\mathrm{NaOAc}, \mathrm{CH}_{3} \mathrm{OH}, 50^{\circ} \mathrm{C}(\mathrm{g}) \mathrm{LiOH} \mathrm{H}_{2} \mathrm{O}, \mathrm{THF}, \mathrm{H}_{2} \mathrm{O}$ 


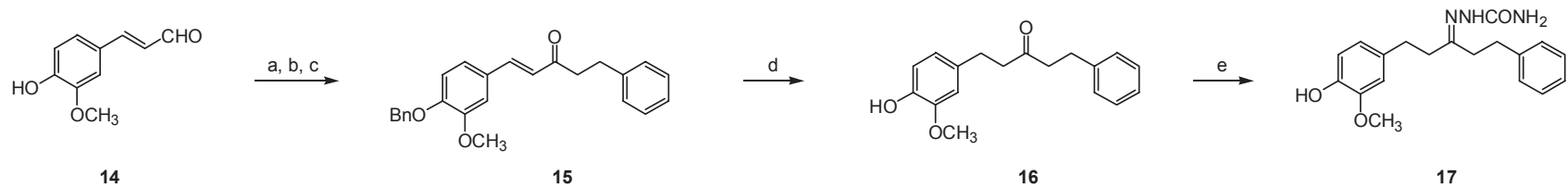

${ }^{a}$ Reaction conditions: (a) $\mathrm{BnBr}, \mathrm{K}_{2} \mathrm{CO}_{3}$, acetone (b) $\mathrm{PhCH}_{2} \mathrm{CH}_{2} \mathrm{MgBr}$, ether (c) PDC, $4 \mathrm{~A} \mathrm{MS}, \mathrm{CH}_{2} \mathrm{Cl}_{2}$ (d) Pd/C, $\mathrm{H}_{2}, \mathrm{MeOH}$ (e) $\mathrm{H}_{2} \mathrm{NHNCONH}_{2}, \mathrm{NaOAc}^{\mathrm{MeOH}}$

Scheme $3^{a}$<smiles>Cc1ccc(CCC(O)CCc2ccccc2)cc1I</smiles>

$18 \mathrm{R}_{1}=\mathrm{CO}_{2} \mathrm{CH}_{3}, \mathrm{R}_{2}=\mathrm{H}$ $19 \mathrm{R}_{1}=\mathrm{H}, \mathrm{R}_{2}=\mathrm{CO}_{2} \mathrm{CH}_{3}$
$20 \mathrm{R}_{1}=\mathrm{CH}_{2} \mathrm{CO}_{2} \mathrm{CH}_{3}, \mathrm{R}_{2}=\mathrm{H}$
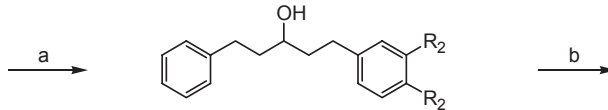

$21 \mathrm{R}_{1}=\mathrm{CO}_{2} \mathrm{H}, \mathrm{R}_{2}=\mathrm{H}$

$22 \mathrm{R}_{1}=\mathrm{H}, \mathrm{R}_{2}=\mathrm{CO}_{2} \mathrm{H}$

$23 \mathrm{R}_{1}=\mathrm{CH}_{2} \mathrm{CO}_{2} \mathrm{H}, \mathrm{R}_{2}=\mathrm{H}$

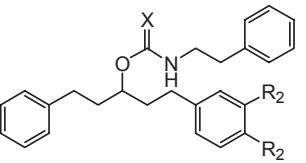

$24 \mathrm{R}_{1}=\mathrm{CO}_{2} \mathrm{H}, \mathrm{R}_{2}=\mathrm{H}, \mathrm{X}=\mathrm{O}$ $25 \mathrm{R}_{1}=\mathrm{CO}_{2} \mathrm{H}, \mathrm{R}_{2}=\mathrm{H}, \mathrm{X}=\mathrm{S}$ $26 \mathrm{R}_{1}=\mathrm{H}, \mathrm{R}_{2}=\mathrm{CO}_{2} \mathrm{H}, \mathrm{X}=\mathrm{S}$
$27 \mathrm{R}_{1}=\mathrm{CH}_{2} \mathrm{CO}_{2} \mathrm{H}, \mathrm{R} 2=\mathrm{H}, \mathrm{X}=\mathrm{S}$

${ }^{a}$ Reaction conditions: (a) $\mathrm{LiOH} \mathrm{H}_{2} \mathrm{O}, \mathrm{THF} / \mathrm{H}_{2} \mathrm{O}$ (b) Phenethylisothiocyanate, $\mathrm{NaH}$, THF

Scheme $4^{a}$

Table 1. Channel activities of synthesized compounds

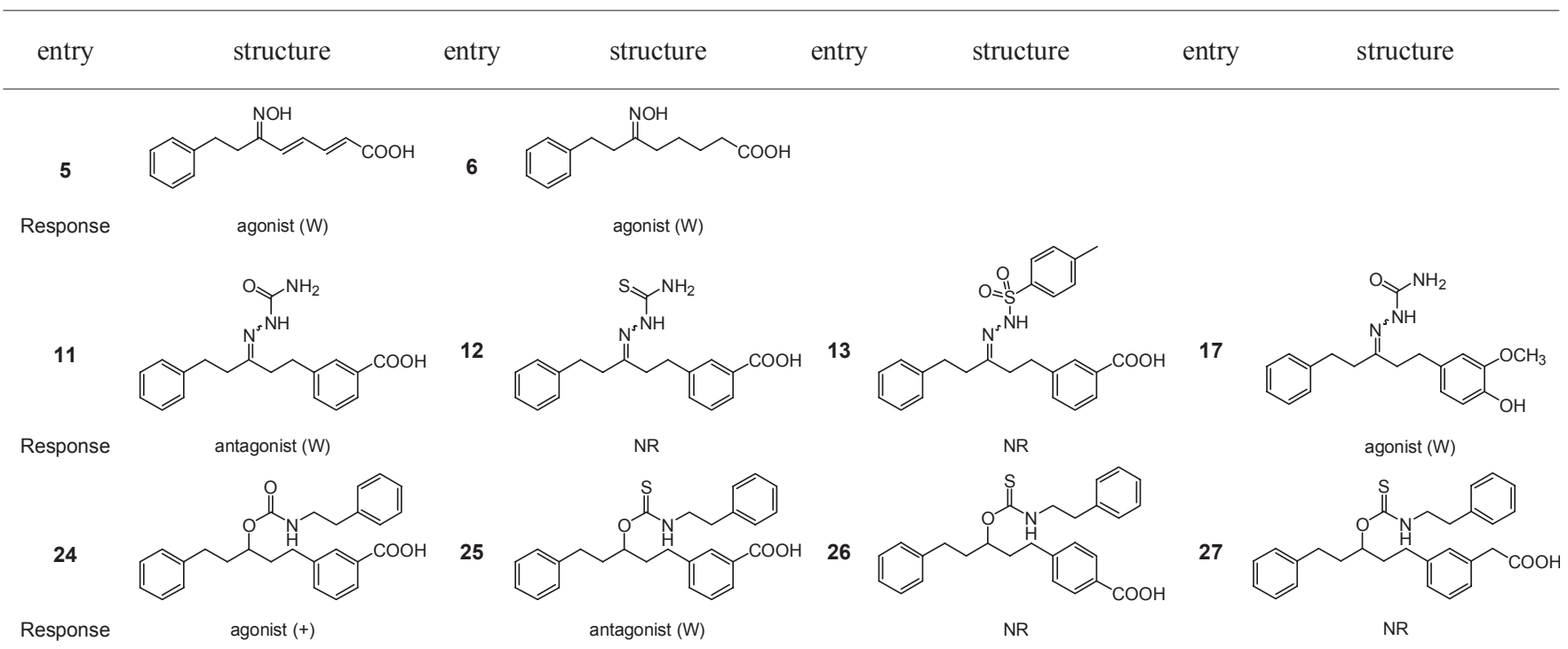

Note: NR (no response), WW (very weak), W (weak), + (equal to capsaicin or capsazepine)

$7 \mathrm{~mL}, 14 \mathrm{mmol}$ ) at $0{ }^{\circ} \mathrm{C}$. The mixture was stirred for $30 \mathrm{~min}$, and then quenched with aq. $\mathrm{NH}_{4} \mathrm{Cl}$, diluted with ether. The organic layer was washed with water and brine, dried with anhydrous $\mathrm{MgSO}_{4}$, filtered and concentrated in vacuo. Column chromatography (EtOAc : $n$-hexane $=1: 3$ ) of the residue gave yellow oil (1.89 g, $6.87 \mathrm{mmol}, 63 \%)$. The alcohol ( $870 \mathrm{mg}, 3.14 \mathrm{mmol})$ was dissolved with imidazole $(280 \mathrm{mg}, 4.11 \mathrm{mmol})$ in DMF $(2 \mathrm{~mL})$. After adding TBSCl (640 mg, $4.11 \mathrm{mmol})$ the mixture was stirred for 1 hour at room temperature, then diluted with ether, washed, dried, filtered, and concentrated in vacuo. Column chromatography (EtOAc : hexane $=1: 10$ ) of the residue gave a colorless oil (1.15 g, $2.95 \mathrm{mmol}, 94 \%)$. The oil (1.02 g, 2.6 $\mathrm{mmol})$ was dissolved in ether, then stirred with $\operatorname{MgBr}_{2}(1.48 \mathrm{~g}$, $7.8 \mathrm{mmol}$ ) at room temperature for 3 hours. The reaction mixture was quenched by water, diluted with ether, washed, dried, filtered, and concentrated in vacuo. Column chromatography (EtOAc : $n$-hexane $=1: 6)$ of the residue gave $2(518 \mathrm{mg}, 1.69$ mmol, 65\%). ${ }^{1} \mathrm{H}-\mathrm{NMR}\left(300 \mathrm{MHz}, \mathrm{CDCl}_{3}\right) \delta 7.11-7.26(\mathrm{~m}, 5 \mathrm{H})$, 5.63-5.80 (m, 2H), 4.10-4.13 (m, 1H), 4.11(d, 2H, J=4.65 Hz), 2.53-2.71 (m, 2H), 1.75-1.87 (m, 2H), 0.88 (s, 9H), 0.28 (s, 6H).

Ethyl (2E,4E)-6-\{ [tert-butyl(dimethyl)silyl]oxy\}-8-phenyl2,4-octadienoate (3). To a solution of 126 (133 mg, $0.434 \mathrm{mmol}$ ) in $\mathrm{CHCl}_{3}(2 \mathrm{~mL})$ was added $\mathrm{MnO}_{2}(888 \mathrm{mg}, 8.68 \mathrm{mmol})$. The reaction mixture was stirred at room temperature for 5 hours, then filtrated, and concentrated in vacuo. The resultant aldehyde was dissolved in methylene chloride $(2 \mathrm{~mL})$, and reacted with (carbethoxymethylene) triphenylphosphorane $(239 \mathrm{mg}$, $0.651 \mathrm{mmol}$ ) at room temperature for 2 hours. After concentration, column chromatography (EtOAc $: n$-hexane $=1: 15)$ of the residue gave ester 3 (113 mg, $0.304 \mathrm{mmol}, 70 \%)$. ${ }^{1} \mathrm{H}-\mathrm{NMR}$ 
$\left(300 \mathrm{MHz}, \mathrm{CDCl}_{3}\right) \delta$ 7.09-7.26 (m, 7H), 6.02-6.31 (m, 1H), 5.57-5.98 (m, 1H), 4.09-4.25 (m, 3H), 2.55-2.63 (m, 2H), 1.76$1.81(\mathrm{~m}, 2 \mathrm{H}), 1.23(\mathrm{t}, 3 \mathrm{H}, J=7.05 \mathrm{~Hz}), 0.857$ (s, 9H), 0.089 (s, $3 \mathrm{H}), 0.048(\mathrm{~s}, 3 \mathrm{H})$.

Ethyl (2E,4E)-6-(hydroxyimino)-8-phenyl-2,4-octadienoate (4). To a solution of $\mathbf{3}(271 \mathrm{mg}, 0.723 \mathrm{mmol})$ in methanol $(2 \mathrm{~mL})$ was added $\mathrm{TsOH}$ (catalytic amount). The reaction mixture was stirred at room temperature for 2 hours, and then neutralized by aq. $\mathrm{NaHCO}_{3}$. The organic layer was diluted with EtOAc, washed, dried, and concentrated in vacuo. Column chromatography of the residue gave alcohol (179 $\mathrm{mg}, 0.687 \mathrm{mmol}, 95 \%)$. To a solution of the alcohol (17 mg, $0.651 \mathrm{mmol})$ in methylene chloride ( $1 \mathrm{~mL}$ ) was added $4 \AA \mathrm{MS}$ and PDC (37 mg, $0.976 \mathrm{mmol}$ ). The mixture was stirred at room temperature for 1 hour, and then diluted with excessive ether, filtrated, and concentrated in vacuo. Column chromatography (EtOAc $: n$-hexane $=1: 5$ ) of the residue gave a ketone intermediate $(14.4 \mathrm{mg}, 0.056 \mathrm{mmol}$, 86\%). ${ }^{1} \mathrm{H}-\mathrm{NMR}\left(300 \mathrm{MHz}, \mathrm{CDCl}_{3}\right) \delta$ 7.08-7.26 (m, 7H), 6.35 $(\mathrm{d}, 1 \mathrm{H}, J=15.1 \mathrm{~Hz}), 6.35(\mathrm{~d}, 1 \mathrm{H}, J=15.1 \mathrm{~Hz}), 6.14(\mathrm{~d}, 1 \mathrm{H}, J=$ $14.9 \mathrm{~Hz}), 4.16$ (q, 2H, $J=7.05 \mathrm{~Hz}), 2.82-2.89$ (m, 4H), 1.24 (t, $3 \mathrm{H}, J=7.05 \mathrm{~Hz})$.

To a solution of the ketone $(12 \mathrm{mg}, 0.0463 \mathrm{mmol})$ in methanol were added $\mathrm{NaOAc}(18 \mathrm{mg}, 0.185 \mathrm{mmol})$ and $\mathrm{NH}_{2} \mathrm{OH} \cdot \mathrm{HCl}$ (12 mg, $0.0926 \mathrm{mmol}$ ). The mixture was stirred at room temperature for 2 hours, and then diluted with EtOAc, washed with sat. $\mathrm{NH}_{4} \mathrm{Cl}$, dried, filtrated and concentrated in vacuo. Column chromatography (EtOAc : $n$-hexane $=1: 2)$ of the residue gave oxime 4 (12 mg, $0.0440 \mathrm{mmol}, 95 \%)$ as a white solid. ${ }^{1} \mathrm{H}-\mathrm{NMR}$ $\left(300 \mathrm{MHz}, \mathrm{CDCl}_{3}\right) \delta$ 7.11-7.36 (m, 6H), 6.35-6.02 (m, 2H), $5.58-6.01(\mathrm{~m}, 1 \mathrm{H}), 4.14$ (q, 2H, $J=7.05 \mathrm{~Hz}), 2.63-2.85(\mathrm{~m}, 4 \mathrm{H})$, $1.24(\mathrm{t}, 3 \mathrm{H}, J=7.05 \mathrm{~Hz})$.

(2E,4E)-6-(Hydroxyimino)-8-phenyl-2,4-octadienoic acid (5). To a solution of 4 (7 mg, $0.0256 \mathrm{mmol})$ in $\mathrm{THF}-\mathrm{H}_{2} \mathrm{O}$ (1:1, $1 \mathrm{~mL})$ was added $\mathrm{LiOH} \cdot \mathrm{H}_{2} \mathrm{O}(3.2 \mathrm{mg}, 0.0768 \mathrm{mmol})$. The mixture was stirred at room temperature for 4 hours, and then acidified with $1 \mathrm{~N} \mathrm{HCl}$, diluted with EtOAc, washed, dried, filtrated, and concentrated in vacuo. Column chromatography (EtOAc : $n$-hexane $\left.=1: 2 \rightarrow \mathrm{CH}_{3} \mathrm{OH}: \mathrm{CH}_{2} \mathrm{CH}_{2}=1: 10\right)$ of the residue gave 131 (6 mg, $0.0 .0244 \mathrm{mmol}, 95 \%)$ as a white solid. ${ }^{1} \mathrm{H}-\mathrm{NMR}$ (300 MHz, $\left.\mathrm{CD}_{3} \mathrm{OD}\right) \delta$ 7.12-7.45 (m, 6H), 6.43-6.66 (m, 2H), 5.87-6.03 (m, 1H), 2.65-2.86 (m, 4H).

6-(Hydroxyimino)-8-phenyloctadienoic acid (6). To a solution of 4 (8 $\mathrm{mg}, 0.0296 \mathrm{mmol})$ in absolute $\mathrm{MeOH}(1 \mathrm{~mL})$ was added $10 \% \mathrm{Pd} / \mathrm{C}$ (catalytic amount). The mixture was stirred under $\mathrm{H}_{2}$ at room temperature for 1 hour, and then diluted with ether, filtrated through celite pad, and concentrated in vacuo. The residue was dissolved in THF- $\mathrm{H}_{2} \mathrm{O}(1: 1,1 \mathrm{~mL})$ with $\mathrm{LiOH} \cdot$ $\mathrm{H}_{2} \mathrm{O}$ (4.30 mg, $\left.0888 \mathrm{mmol}\right)$. The mixture was stirred at room temperature for 4 hours, and then acidified with $1 \mathrm{~N} \mathrm{HCl}$, diluted with $\mathrm{CH}_{2} \mathrm{Cl}_{2}$, washed, dried, filtrated and concentrated in vacuo. Column chromatography of the residue (EtOAc : $n$-hexane $=$ $\left.1: 2 \rightarrow \mathrm{CH}_{3} \mathrm{OH}: \mathrm{CH}_{2} \mathrm{CH}_{2}=1: 10\right)$ gave acid 6 (3 mg, 0.120 mmol, 42\%). ${ }^{1} \mathrm{H}-\mathrm{NMR}\left(300 \mathrm{MHz}, \mathrm{CDCl}_{3}\right) \delta$ 7.10-7.24 (m, 3H), 2.71-2.81 (m, 2H), 2.55-2.68 (m, 2H), 2.28-2.45 (m, 4H), 1.97$2.05(\mathrm{~m}, 2 \mathrm{H}), 1.54(\mathrm{~m}, 2 \mathrm{H})$.

5-Phenyl-pent-1-yn-3-ol (8). To a solution of oxalyl chloride $(0.38 \mathrm{~mL}, 4.4 \mathrm{mmol})$ in methylene chloride $(14 \mathrm{~mL})$ was added dropwise DMSO $(0.44 \mathrm{~mL}, 6.24 \mathrm{mmol})$ at $-78^{\circ} \mathrm{C}$. After $20 \mathrm{~min}$, a solution of 3-phenyl-1-propanol (500 mg, $3.67 \mathrm{mmol})$ in methylene chloride (4 mL) was added. After $30 \mathrm{~min}$, triethylamine $(1.5 \mathrm{~mL}, 10.65 \mathrm{mmol})$ was added dropwise at room temperature. The reaction mixture was stirred at room temperature and then quenched by aq. $\mathrm{NH}_{4} \mathrm{Cl}$, diluted, washed, dried and concentrated in vacuo. Column chromatography (EtOAc: Hexane $=1: 3$ ) of the residue gave aldehyde (490 mg, 3.65 mmol, $99 \%$ ). To a solution of the aldehyde in ether $(10 \mathrm{~mL})$ was added dropwise ethynyl magnesium bromide $(0.5 \mathrm{M}$ solution in THF, $8.8 \mathrm{~mL}, 4.33 \mathrm{mmol}$ ) at $0{ }^{\circ} \mathrm{C}$. The mixture was stirred at room temperature for 2 hours, and then quenched by aq. $\mathrm{NH}_{4} \mathrm{Cl}$, diluted with ether, washed, dried, and concentrated in vacuo. Column chromatography (EtOAc : Hexane $=1: 4$ ) of the residue gave alcohol 8 (410 mg, 70\%). ${ }^{1} \mathrm{H}-\mathrm{NMR}\left(300 \mathrm{MHz}, \mathrm{CDCl}_{3}\right)$ $\delta 7.19-7.33(\mathrm{~m}, 5 \mathrm{H}), 4.38(\mathrm{dt}, 1 \mathrm{H}, J=6.6 \mathrm{~Hz}), 2.82(\mathrm{t}, 2 \mathrm{H}, J=$ $8 \mathrm{~Hz}), 2.51(\mathrm{~d}, 1 \mathrm{H}, J=2.2 \mathrm{~Hz}), 2.01-2.09(\mathrm{~m}, 2 \mathrm{H})$.

3-(3-Hydroxy-5-phenyl-pent-1-ynyl)-benzoic acid methyl ester (9). To a mixture of alcohol 8 (200 mg, $1.25 \mathrm{mmol})$ and iodobenzoic acid methyl ester (327 mg, $1.25 \mathrm{mmol})$ in THF were added triethylamine (0.35 mL, $2.5 \mathrm{mmol}), \mathrm{CuI}(20 \mathrm{mg}, 0.125$ $\mathrm{mmol}), \mathrm{Pd}\left(\mathrm{PPh}_{3}\right)_{2} \mathrm{Cl}(44 \mathrm{mg}, 0.063 \mathrm{mmol})$. The mixture was stirred at room temperature for $40 \mathrm{~min}$, and then diluted with ether, filtrated through celite pad, and concentrated in vacuo. Column chromatography (EtOAc $: n$-Hexane $=1: 6 \rightarrow 1: 4$ ) of the residue gave 9 (360 $\mathrm{mg}, 98 \%$ ). IR (KBr) 3444, 2950, 1729 , 1436, 1299, 1044, 754; ${ }^{1} \mathrm{H}-\mathrm{NMR}\left(300 \mathrm{MHz}, \mathrm{CDCl}_{3}\right) \delta 8.09(\mathrm{t}$, $1 \mathrm{H}, J=1.44 \mathrm{~Hz}), 7.97(\mathrm{dt}, 1 \mathrm{H}, J=1.44,7.8 \mathrm{~Hz}), 7.58(\mathrm{dt}, 1 \mathrm{H}$, $J=1.47,7.56 \mathrm{~Hz}), 7.38(\mathrm{t}, 1 \mathrm{H}, J=7.8 \mathrm{~Hz}), 7.16-7.31(\mathrm{~m}, 5 \mathrm{H})$, $4.59(\mathrm{t}, 1 \mathrm{H}, J=6.6 \mathrm{~Hz}), 3.91(\mathrm{~s}, 3 \mathrm{H}), 2.85(\mathrm{t}, 2 \mathrm{H}, J=7.8 \mathrm{~Hz})$, $2.03-2.20(\mathrm{~m}, 2 \mathrm{H}), 1.99(\mathrm{~d}, 1 \mathrm{H}, J=4.89 \mathrm{~Hz}) ;{ }^{13} \mathrm{C}-\mathrm{NMR}\left(\mathrm{CDCl}_{3}\right.$, $75 \mathrm{MHz}) 166.34,141.11,135.76,132.75,130.29,029.35$, $128.46,128.41,125.98,122.97,90.80,84.09,62.05,52.26$, 39.14, 31.39.; LRMS (LC/MS) 294 (M).

Methyl 3-(3-ox0-5-phenyl-pentyl)-benzoate (10). To a solution of $9(250 \mathrm{mg}, 0.35 \mathrm{mmol})$ in methanol $(4 \mathrm{~mL})$ was added $10 \% \mathrm{Pd} / \mathrm{C}$ (catalytic amount). The mixture was stirred under $\mathrm{H}_{2}$ at room temperature for 2 hours, and then diluted with ether, filtrated through celite pad. Concentration in vacuo gave saturated ester (253 mg, 99\%) as a colorless oil. ${ }^{1} \mathrm{H}-\mathrm{NMR}(300 \mathrm{MHz}$, $\left.\mathrm{CDCl}_{3}\right) \delta$ 7.77-7.80 (m, 2H), 7.09-7.32 (m, 7H), $3.83(\mathrm{~s}, 3 \mathrm{H})$, $3.58(\mathrm{~m}, 1 \mathrm{H}), 2.54-2.82(\mathrm{~m}, 4 \mathrm{H}), 1.66-1.79(\mathrm{~m}, 4 \mathrm{H}) ;{ }^{13} \mathrm{C}-\mathrm{NMR}$ $\left(100 \mathrm{MHz}, \mathrm{CDCl}_{3}\right)$ 167.26, 142.46, 141.96, 133.10, 130.18, 129.46, 128.41, 128.38, 128.35, 127.12, 125.81, 70.48, 52.04, $39.20,38.99,32.00,31.76,20.99,14.15$.

To a solution of the saturated ester $(17 \mathrm{mg})$ in methylene chloride $(1 \mathrm{~mL})$ was added $4 \AA \mathrm{MS}$ and PDC (37 mg, 0.976 mmol). The mixture was stirred at room temperature for 1 hour, and then diluted with excessive ether, filtrated, and concentrated in vacuo. Column chromatography (EtOAc : $n$-hexane $=1: 5)$ of the residue gave $10(86 \%)$. ${ }^{1} \mathrm{H}-\mathrm{NMR}\left(300 \mathrm{MHz}, \mathrm{CDCl}_{3}\right) \delta$ 7.77-7.80 (m, 2H), 7.06-7.32 (m, 7H), 3.83 (s, 3H), 2.74-2.88 (m, 4H), 2.62-2.68 (m, 4H).

General procedure for preparation of hydrozono compounds. To a solution of Semicarbazide $\mathrm{HCl}$ (1 eq.) in $\mathrm{MeOH}$ were added $\mathrm{NaOAc}\left(2\right.$ eq.) and a ketone $\left(1\right.$ eq.) at $0{ }^{\circ} \mathrm{C}$. The mixture was heated slowly to $70{ }^{\circ} \mathrm{C}$ and then concentrated in vacuo. The residue was dissolved in $\mathrm{THF} / \mathrm{H}_{2} \mathrm{O}(1: 1)$ with $\mathrm{LiOH} \mathrm{H}_{2} \mathrm{O}$ (2 eq.). The mixture was stirred at room temperature for 1 hour 
and then acidified with $1 \mathrm{~N} \mathrm{HCl}$ to be $\mathrm{pH}$ 5, diluted with EtOAc, dried and concentrated in vacuo. Column chromatography (Me$\left.\mathrm{OH}: \mathrm{CH}_{2} \mathrm{Cl}_{2}=1: 20\right)$ was carried out.

3-\{3-[2-(Aminocarbonyl)hydrazono]-5-phenylpentyl $\}$ ben zenecarboxylicacid (11). ${ }^{1} \mathrm{H}-\mathrm{NMR}\left(300 \mathrm{MHz}, \mathrm{CDCl}_{3}\right) \delta 8.05 \&$ 7.78-7.83 (m, 2H), 7.08-7.33 (m, 7H), $3.85 \& 3.83$ (s, 3H), 2.66$2.83(\mathrm{~m}, 4 \mathrm{H}), 2.37-2.54(\mathrm{~m}, 4 \mathrm{H})$.

3-\{3-[2-(Aminocarbothioyl)hydrazono]-5-phenylpentyl\}benzenecarboxylicacid (12). ${ }^{1} \mathrm{H}-\mathrm{NMR}\left(300 \mathrm{MHz}, \mathrm{CDCl}_{3}\right) \delta$ 7.84-7.88 (m, 2H), 7.28-7.36 (m, 2H), 7.07-7.23 (m, 5H), 2.81$2.91(\mathrm{~m}, 4 \mathrm{H}), 2.64-2.70(\mathrm{~m}, 4 \mathrm{H})$.

3-(3-\{2-[(4-Methylphenyl)sulfonyl]hydrazono\}-5-phenyl pentyl)benzene carboxylic acid (13). ${ }^{1} \mathrm{H}-\mathrm{NMR}(300 \mathrm{MHz}$, $\left.\mathrm{CDCl}_{3}\right) \delta$ 7.65-8.02 (m, 4H), 7.16-7.26 (m, 7H), 6.96-7.04 (m, $2 \mathrm{H}), 2.66-2.87(\mathrm{~m}, 4 \mathrm{H}), 2.40-2.46(\mathrm{~m}, 7 \mathrm{H})$.

(E)-1-[4-(Benzyloxy)3-methoxyphenyl]-5-phenyl-1-penten3-one (15). ${ }^{1} \mathrm{H}-\mathrm{NMR}\left(300 \mathrm{MHz}, \mathrm{CDCl}_{3}\right) \delta$ 7.10-7.42 (m, 12H), 6.94-6.99 (m, 2H), $6.80(\mathrm{~d}, 1 \mathrm{H}, J=8.3 \mathrm{~Hz}), 6.53(\mathrm{~d}, 1 \mathrm{H}, J=$ $16.0 \mathrm{~Hz}), 5.12$ (s, 2H), 3.84 (s, 2H), 2.92 (s, 4H).

1-(4-Hydroxy-3-methoxyphenyl)-5-phenyl-3-pentanone (16). ${ }^{1} \mathrm{H}-\mathrm{NMR}\left(300 \mathrm{MHz}, \mathrm{CDCl}_{3}\right) \delta$ 7.06-7.22 (m, 5H), 6.74 (m, 1H), 6.55-6.58 (m, 2H), $3.78(\mathrm{~s}, 3 \mathrm{H}), 2.72-2.83(\mathrm{~m}, 4 \mathrm{H})$, 2.58-2.66 (m, 4H).

2-[1-(4-Hydroxy-3-methoxyphenethyl)-3-phenylpropylidene]-1-hydrazinecarboxamide (17). ${ }^{1} \mathrm{H}-\mathrm{NMR}(300 \mathrm{MHz}, \mathrm{CD}-$ $\left.\mathrm{Cl}_{3}\right) \delta 7.70 \& 7.65(\mathrm{~s}, 1 \mathrm{H}), 7.07-7.24(\mathrm{~m}, 5 \mathrm{H}), 6.76(\mathrm{~m}, 1 \mathrm{H})$, 6.55-6.58 (m, 2H), 5.41 (br s, 1H), $3.80 \& 3.79$ (s, 3H), 2.62$2.80(\mathrm{~m}, 4 \mathrm{H}), 2.32-2.44(\mathrm{~m}, 4 \mathrm{H})$.

3-(3-Hydroxy-5-phenyl-pentyl)-benzoic acid (21). To a solution of $18(100 \mathrm{mg}, 0.335 \mathrm{mmol})$ in $\mathrm{THF} / \mathrm{H}_{2} \mathrm{O}(1: 1,3 \mathrm{~mL})$ was added $\mathrm{LiOH} \cdot \mathrm{H}_{2} \mathrm{O}(70 \mathrm{mg}, 1.68 \mathrm{mmol})$. The mixture was stirred at $35^{\circ} \mathrm{C}$ for 6 hours, and then acidified with $1 \mathrm{~N} \mathrm{HCl}$, diluted with EtOAc, washed, dried and concentrated in vacuo. Column chromatography $\left(\mathrm{MeOH}: \mathrm{CH}_{2} \mathrm{Cl}_{2}=1: 20\right)$ gave 21 (76 mg, $80 \%) .{ }^{1} \mathrm{H}-\mathrm{NMR}\left(300 \mathrm{MHz}, \mathrm{CDCl}_{3}\right) \delta 7.86-7.88(\mathrm{~m}, 2 \mathrm{H}), 7.10-$ $7.38(\mathrm{~m}, 7 \mathrm{H}), 3.57-3.65(\mathrm{~m}, 1 \mathrm{H}), 2.56-2.85(\mathrm{~m}, 4 \mathrm{H}), 1.71-1.82$ $(\mathrm{m}, 4 \mathrm{H})$.

3-(3-Phenethylthiocarbamoyloxy-5-phenyl-pentyl)-benzoic acid (24). To a suspension of 95\% $\mathrm{NaH}(10 \mathrm{mg}, 0.424 \mathrm{mmol})$ in THF was added a solution of $21(30 \mathrm{mg}, 0.106 \mathrm{mmol})$ in THF $(2 \mathrm{~mL})$ at $0{ }^{\circ} \mathrm{C}$. After $10 \mathrm{~min}, \mathrm{Ph}\left(\mathrm{CH}_{2}\right)_{2} \mathrm{NCS}(50 \mu \mathrm{L}, 0.306$ $\mathrm{mmol}$ ) was added. The reaction mixture was stirred at room temperature for 2 hours, and then quenched by aq. $\mathrm{NH}_{4} \mathrm{Cl}$, diluted with EtOAc, washed, dried and concentrated in vacuo. Column chromatography (EtOAc : Hexane $=1: 2 \rightarrow \mathrm{MeOH}$ : $\left.\mathrm{CH}_{2} \mathrm{Cl}_{2}=1: 20\right)$ gave $24(33 \mathrm{mg}, 70 \%) .{ }^{1} \mathrm{H}-\mathrm{NMR}(300 \mathrm{MHz}$, $\left.\mathrm{CDCl}_{3}\right) \delta 7.93(\mathrm{~d}, 2 \mathrm{H}, J=8.1 \mathrm{~Hz}), 7.09-7.23(\mathrm{~m}, 11 \mathrm{H}), 6.58 \&$ $6.02(\mathrm{t}, 1 \mathrm{H}), 3.66-3.78(\mathrm{~m}, 2 \mathrm{H}), 2.57-2.89(\mathrm{~m}, 6 \mathrm{H}), 1.78-2.06$ $(\mathrm{m}, 4 \mathrm{H})$.

3-(3-Phenethylcarbamoyloxy-5-phenyl-pentyl)-benzoic acid (25). To a solution of $18(21 \mathrm{mg}, 0.0703 \mathrm{mmol})$ in benzene was added $\mathrm{Ph}\left(\mathrm{CH}_{2}\right)_{2} \mathrm{NCO}(40 \mu \mathrm{L}, 0.0 .281 \mathrm{mmol})$. The mixture was refluxed for 5 hours, and then concentrated in vacou. After column chromatography (EtOAc $:$ Hexane $=1: 2 \rightarrow \mathrm{MeOH}$ : $\left.\mathrm{CH}_{2} \mathrm{Cl}_{2}=1: 20\right)$ of the residue, the resulting ester was hydrolyzed by $\mathrm{LiOH} \mathrm{H}_{2} \mathrm{O}$ same as the above described. ${ }^{1} \mathrm{H}-\mathrm{NMR}$ $\left(300 \mathrm{MHz}, \mathrm{CDCl}_{3}\right) \delta$ 7.85-7.87 (m, 2H), 7.08-7.34 (m, 12H), $4.81(\mathrm{~m}, 1 \mathrm{H}), 4.59(\mathrm{~m}, 1 \mathrm{H}), 3.29-3.41(\mathrm{~m}, 2 \mathrm{H}), 2.69-2.79(\mathrm{~m}$, $2 \mathrm{H}), 2.49-2.64(\mathrm{~m}, 4 \mathrm{H}), 1.80-1.83(\mathrm{~m}, 4 \mathrm{H})$.

Methyl 4-(3-hydroxy-5-phenylpentyl)benzenecarboxylate (19). ${ }^{1} \mathrm{H}-\mathrm{NMR}\left(300 \mathrm{MHz}, \mathrm{CDCl}_{3}\right) \delta 7.93(\mathrm{dd}, 2 \mathrm{H}, J=1.6,6.6$ $\mathrm{Hz}), 7.14-7.32$ (m, 7H), 3.88 (s, 3H), 3.63 (m, 1H), 2.59-2.87 (m, 4H), 1.71-1.82 (m, 4H).

4-(3-Hydroxy-5-phenylpentyl)benzenecarboxylic acid (22). ${ }^{1} \mathrm{H}-\mathrm{NMR}\left(300 \mathrm{MHz}, \mathrm{CDCl}_{3}\right) \delta 7.95(\mathrm{~d}, 2 \mathrm{H}, J=8.2 \mathrm{~Hz}), 7.10-$ $7.23(\mathrm{~m}, 7 \mathrm{H}), 3.60(\mathrm{~m}, 1 \mathrm{H}), 2.55-2.85(\mathrm{~m}, 4 \mathrm{H}), 1.70-1.78(\mathrm{~m}$, $4 \mathrm{H})$.

4-(3-\{[(Phenethylamino)carbothioyl $]$ oxy $\}$-5-phenylpentyl) benzenecarboxylic acid (26). ${ }^{1} \mathrm{H}-\mathrm{NMR}\left(300 \mathrm{MHz} \mathrm{CDCl}_{3}\right) \delta$ $7.93(\mathrm{~d}, 2 \mathrm{H}, J=8.0 \mathrm{~Hz}), 7.08-7.24(\mathrm{~m}, 12 \mathrm{H}), 6.57 \& 6.02(\mathrm{~m}$, $1 \mathrm{H}), 5.55(\mathrm{~m}, 1 \mathrm{H}), 3.74(\mathrm{~m}, 1 \mathrm{H}), 3.38(\mathrm{~m}, 2 \mathrm{H}), 2.26-2.89(\mathrm{~m}$, $5 \mathrm{H}), 1.78-2.05(\mathrm{~m}, 4 \mathrm{H})$.

Methyl 2-[3-(3-hydroxy-5-phenylpentyl)phenyl]acetate (20). ${ }^{1} \mathrm{H}-\mathrm{NMR}\left(300 \mathrm{MHz}, \mathrm{CDCl}_{3}\right) \delta$ 7.00-7.22 (m, 9H), $3.60(\mathrm{~s}, 3 \mathrm{H})$, $3.55(\mathrm{~m}, 1 \mathrm{H}), 3.51(\mathrm{~s}, 2 \mathrm{H}), 2.52-2.75(\mathrm{~m}, 4 \mathrm{H}), 1.64-1.80(\mathrm{~m}, 4 \mathrm{H})$.

2-[3-(3-Hydroxy-5-phenylpentyl)phenyl]acetic acid (23). ${ }^{1} \mathrm{H}-\mathrm{NMR}\left(300 \mathrm{MHz}, \mathrm{CDCl}_{3}\right) \delta$ 7.02-7.23 (m, 9H), $3.60(\mathrm{~m}, 1 \mathrm{H})$, $3.50(\mathrm{~s}, 2 \mathrm{H}), 2.48-2.76(\mathrm{~m}, 4 \mathrm{H}), 1.62-1.78(\mathrm{~m}, 4 \mathrm{H})$.

2-[3-(3-\{[(Phenethylamino)carbothioyl]oxy\}-5-phenylpentyl)phenyl]acetic acid (27). ${ }^{1} \mathrm{H}-\mathrm{NMR}\left(300 \mathrm{MHz}, \mathrm{CDCl}_{3}\right) \delta$ 7.00-7.25 (m, 9H), $6.74 \& 6.05$ (br t, $1 \mathrm{H}, J=5.8 \mathrm{~Hz}), 5.52(\mathrm{~m}$, $1 \mathrm{H}), 3.69 \& 3.33$ (q, $2 \mathrm{H}, J=6.6 \mathrm{~Hz}), 3.52(\mathrm{~s}, 2 \mathrm{H}), 2.84 \& 2.72$ $(\mathrm{t}, 2 \mathrm{H}, J=7.0 \mathrm{~Hz}), 2.54-2.59(\mathrm{~m}, 4 \mathrm{H}), 1.84-2.00(\mathrm{~m}, 4 \mathrm{H})$.

Acknowledgments. We thank Professor Uhtaek Oh for his support of this work. This research was supported by the grant from Amore Pacific Corporation.

\section{References}

1. (a) Szallasi, A.; Blumberg, P. M. Pharmacol. Rev. 1999, 51, 159212. (b) Szallasi, A.; Cortright, D. N.; Blum, C. A.; Eid, S. R. Nat. Rev. Drug Discov. 2007, 6, 357-372.

2. Bley, K. R. Expert Opin. Investig. Drugs 2004, 13, 1445-1456.

3. Wood, J. Capsaicin in the Study of Pain; Academic press: San Diego, 1993.

4. (a) Gunthorpe, M. J.; Chizh, B. A. Drug Discov. Today 2009, 14, 1-2, 56-67. (b) Pal, M.; Angaru, S.; Kodimuthali, A.; Dhingra, N. Curr. Pharm. Des. 2009, 15, 9, 1008-1026.

5. Caterina, M. J.; Schumacher, M. A.; Tominaga, M.; Rosen, T. A.; Levine, J. D.; Julius, D. Nature 1997, 389, 816-824.

6. Hwang, S. W.; Cho, H.; Kwak, J.; Lee, S. Y.; Kang, C. J.; Jung, J.; Cho, S.; Min, K. H.; Suh, Y. G.; Kim, D.; Oh, U. Proc. Natl. Acad. Sci. USA 2000, 97, 6155-6160.

7. Corey. E. J.; William, S. Tetrahedron Lett. 1975, 16, 2647-2650.

8. Omura, K.; Swern, D. Tetrahedron 1978, 34(11), 1651-1660.

9. Just, G.; Singh, R. Tetrahedron Lett. 1987, 28, 5981-5984. 